\title{
METHODOLOGICAL APPROACH TO THE ELABORATION OF INDICATORS FOR QUANTIFYING THE COMPETITIVENESS OF GOODS
}

\author{
Tatiana GUTIUM 1, PhD Student, \\ National Institute for Economic Research, Republic of Moldova
}

DOI: https://doi.org/10.36004/nier.es.2020.1-07

JEL Classification: C13, C43, 020

UDC: 339.137.24

\section{ABSTRACT}

The period of temporary economic isolation caused by the Covid-19 pandemic has affected the economies of all countries in the world. After quarantine and the gradual restoration of the activity of all economic sectors, competition in the world market will intensify. Countries will promote strategies for economic growth, improving economic security, increasing exports, and protecting domestic producers. Given the fact that resources are limited and exhaustible, it is necessary to correctly identify priority sectors when developing strategies. For this purpose, the competitiveness index can be used, since competitiveness is one of the main characteristics that allows anyone to determine its position on the market, and increasing competitiveness ensures victory in the competition. The novelty and purpose of the study is to develop two new integral indices, and to improve one symmetric index of comparative advantage developed earlier. Some of empirical and theoretical methods were used in this research: abstraction, the method of ascending from the abstract to the concrete, comparison, measurement, analysis and synthesis, economic and mathematical modelling. To identify priority sectors, the author used the developed indices to assess the competitiveness of goods, not only on the foreign market, but also on the domestic market. This study can serve economists as a tool for assessing the competitiveness of goods, identifying the strengths and weaknesses of the goods offered, in the context of developing measures to increase competitiveness, which will increase the profitability of entrepreneurship.

Keywords: competitiveness of goods, integral index, symmetrical index of comparative advantage, internal market, foreign market, monofactorial models, bifactorial models, Republic of Moldova.

Perioada de izolare economică temporară, cauzată de pandemia Covid-19, a afectat economiile tuturor țărilor lumii. După ieșirea din carantină și restabilirea treptată a tuturor domeniilor economice, se va acutiza concurența pe piața mondială. Țările vor promova strategii de creștere economică, sporire a securității economice, majorare a exportului, protejare a producătorului autohton. Tinând cont de faptul, că resursele sunt limitate și epuizabile, la elaborarea strategiilor este necesar corect de determinat ramurile prioritare. În acest scop, poate fi utilizat indicele competitivității, deoarece, anume competitivitatea este una din caracteristicele de bază, care permite determinarea poziției pe piață, iar sporirea competitivității asigură victorie în lupta concurențială. Noutatea și scopul cercetării constă în elaborarea a doi indici integrali noi, și îmbunătătirea unui indice simetric al avantajului comparativ elaborat anterior. În studiul dat au fost utilizate următoarele metode empirice și teoretice: abstractizarea, metoda ascensiunii de la abstract la concret, comparația, măsurarea, analiza și sinteza, modelarea economico-matematică. În scopul determinării ramurilor prioritare, autorul a utilizat indicii elaborați la estimarea competitivității bunurilor nu numai pe piața externă, dar și pe piața internă. Studiul dat poate servi ca instrumentariu pentru economiști la estimarea competitivității bunurilor, depistarea punctelor tari și slabe ale bunurilor oferite, în contextul elaborării măsurilor de sporire a competitivității, care ar asigura majorarea profitabilității activității de antreprenoriat.

Cuvinte-cheie: competitivitatea bunurilor, indice integral, indice simetric al avantajului comparativ, piața internă, piața externă, modele monofactoriale, modele bifactoriale, Republica Moldova.

\section{1 (C) Tatiana GUTIUM, gutium.tatiana1@gmail.com}


Период временной экономической изоляции, вызванной пандемией Covid-19, затронул экономики всех стран мира. После карантина и постепенного восстановления деятельности всех экономических секторов, конкуренция на мировом рынке усилится. Сттраны будут продвигать стратегии экономического роста, повышения экономической безопасности, увеличения экспорта, защиты отечественного производителя. Учитывая тот факт, что ресурсы ограничены и исчерпаемы, необходимо правильно определить приоритетные отрасли при разработке стратегий. Для этой цели может быть использован индекс конкурентоспособности, так как, именно конкурентоспособность является одной из основных характеристик, которая позволяет определить позицию на рынке, а повышение конкурентоспособности обеспечивает победу в конкурентной борьбе. Новизна и цель исследования состоит в разработке двух новых интегральных индексов, и усовершенствовании одного симметричного индекса сравнительного преимущества разработаного ранее. В этом исследовании использовались следующие эмпирические и теоретические методы: абстракция, метод восхождения от абстрактного к конкретному, сравнение, измерение, анализ и синтез, экономико-математическое моделирование. Для определения приоритетных отраслей, автор использовал разработанные индексы для оценки конкурентоспособности товаров, не только на внешнем рынке, но и на внутреннем рынке. Данное исследование может служить для экономистов в качестве инструментария оценки конкурентоспособности товаров, выявления сильных и слабых сторон предлагаемых товаров, в контексте разработки мер по повышению конкурентоспособности, которые обеспечат повышение прибыльности предпринимательства.

Ключевые слова: конкурентоспособность товара, интегральный индекс, симметричный индекс сравнительного преимущества, внутренний рынок, внешний рынок, однофакторные модели, двухфакторные модели, Республика Молдова.

\section{INTRODUCTION}

2020 is a difficult year. World economies are waiting for an economic crisis. In order to withstand the conditions of reduction of payments in the state budget, increasing unemployment and decreasing the solvency of the population, countries will have to pursue a policy of protecting domestic producers.

Moldova's economy is more vulnerable than the economy of trading partners. In order to withstand the conditions of political and economic instability, this year's natural cataclysms, reduction of remittances, technical unemployment during the Covid-19 pandemic, decreasing of population incomes, Moldova should reassess its resources, make rational decisions in the field of financial support and correctly identify priority sectors, produce and offer competitive products on both domestic and foreign markets. Therefore, it is relevant to develop indices that would allow the quantification of the competitiveness of domestic goods depending on several factors; and these indices can be used to identify the priority branches of industry.

The purpose of the research is to develop indicators to assess the competitiveness of domestic goods in the internal and external markets, which would take into account the factors influencing competitiveness, based on the availability of statistical data.

Methods of the study are the index method, economic and mathematical modelling. This study is a continuation of the author's research previously published in following articles:

$\checkmark$ Quantifying the comparative advantage of domestic goods on the internal market. In: The Journal Contemporary Economy. 2018, volume 3, issue 1.

$\checkmark$ Classification of the competitiveness' factors and new approaches to assessing the competitiveness. In: Economy and sociology. 2018, no. 2.

The novelty of this study consists in the elaboration of two integral indices of competitiveness, one for estimating the competitiveness of domestic goods on the internal market, the second for quantifying the competitiveness of goods on the external market and determining the priority branches of industry.

\section{THE SCIENTIFIC APPROACH OF THE TOPIC IN THE LITERATURE}

The competitiveness of goods can be calculated using a comparative advantage index or an integral index. The research objectives are to improve the first index and to develop the second one. 
The object of study of most domestic and foreign economists is the competitiveness of the enterprise and not the competitiveness of goods. As the main objective of trade policy is to promote goods on the external market, research is mainly carried out on the competitiveness of goods on this market, but there are very few studies on the competitiveness of goods on the internal market. This trend created the following situation: despite the fact that the Republic of Moldova is an agricultural country, for some goods it partially lost its own market, and the share of imports of tomatoes, cucumbers, other agricultural products and foodstuffs is gradually increasing. The countries of origin of these products are Turkey, Ukraine, Romania, Poland, Belarus, Northern Macedonia, but not Moldova.

The competitiveness indices cited in the scientific literature assess the comparative advantages of goods, especially on the external market (Balassa et al. 1989; Group 1994; Dalum et al. 1998; Siggel 2006; Berkowitz et al. 2006; Hidalgo et al. 2007; Yu et al. 2009; Hausmann et al. 2011; Costinot et al. 2012; Barter 2014). On the other hand, as mentioned, the assessment of goods' competitiveness on the internal market is neglected.

Moldavian economists argue that the main methods of quantifying competitiveness are the differential and complex methods.

In case of the differential method, the competitiveness is evaluated "as the ratio between the values of the parameter of the analyzed goods and of the commodity taken as a basis of comparison. As a parameter there can be used price, production and sales cost, indices of goods quality, such as reliability, durability, maintainability" (Popa et al. 2017: 80).

The calculation of competitiveness based on specific indices has both advantages and disadvantages. The advantage of the described method is that it allows to identify the competitive advantages of the studied object, and the deficiency of the differential method is that the assessment of competitiveness in relation to one parameter is not representative. Therefore, it is necessary to use this method together with a complex method.

The complex method consists in calculating group indicators for regulatory, technical, economic parameters and an integrated index of goods' competitiveness (Popa et al. 2017: 80-81; Safiullin et al. 2008: 84-85). This method is often used, but it is also not perfect. A significant shortcoming of the complex method is that consumer preferences are not taken into account.

In addition to the mentioned methods, there is a third method - the mixed method, which consists in combining specific and integral indices.

All these methods contain common shortcomings:

$\checkmark$ They do not take into account that the world economy is constantly changing and new factors appear to influence competitiveness;

$\checkmark$ Product life cycle phases are not taken into account;

$\checkmark$ Insufficiency of the information base.

A comparative analysis of competitiveness assessment methods used in the research of modern scientists has shown that both simplified indicators and complex models are used.

An example of a simplified method is one based on the calculation of the ratio of quality and price (Safiullin et al. 2008: 83):

$$
K_{j}=\frac{C_{j}}{P_{j}}
$$

where:

$K_{j}$ - the competitiveness coefficient of goods $j$;

$C_{j}$ - the quality of goods $j$;

$P_{j}$ - the price of goods $j$.

"The goods with an optimal ratio of these characteristics are the most competitive" (Safiullin et al. 2008: 83).

The complex models developed in recently published scientific papers relate to assessing competitiveness at the sector, enterprise level, in the context of promoting economic policy, but not competitiveness of goods:

$\checkmark$ Michael Peneder's Iceberg Model (Peneder 2017:839);

$\checkmark$ IQCP Model (Innovation, Quality, Competitiveness and Performance) (Al-Shuaibi 2016:101). 
However, these models can be adapted to assess the goods' competitiveness.

According to the Iceberg model, the main goal (the tip of the iceberg) is productivity, because „this indicator is able to aggregate the influence of many relevant variables” (Peneder 2017:838). In the author's opinion, the idea underlying the development of this model can be used to estimate the competitiveness of the goods, it is only necessary to select those indicators that are relevant and reflect factors affecting the competitiveness of the goods.

Evidence that the reasoning of Michael Peneder can be used not only to assess competitiveness at the mesoeconomic level, but also at the microeconomic (commodity) level, can be provided by the following cause-effect relationships:

$\checkmark$ An increase of labor productivity leads to a decrease of production cost and price, so the commodity becomes more competitive;

$\checkmark$ The increase in labor productivity can be achieved through the use of advanced technologies, innovations, therefore, in addition to increasing labor efficiency, there is an increase in the quality of goods, which is one of the factors of competitiveness.

SYMMETRIC INDEX OF THE COMPARATIVE ADVANTAGE OF THE DOMESTIC GOOD ON THE INTERNAL MARKET: IMPROVEMENT AND APPLICATION

Taking as a basis the previously developed algorithm (Gutium 2018:41-42) and modifying it, eliminating the discovered shortcomings caused by the instability of trade rela tions that leads to a significant increase of stocks of goods, the author obtained the calculation formula described in equations 2 and 3. For example, the share of changes in stocks of canned vegetables and fruits in the volume of production and the volume of imports amounted to $52.9 \%$ in 2017, and in 2018 it was only $18.3 \%$.

$$
\begin{gathered}
I C A D_{i}^{S E}=\frac{Q_{i}^{D^{S E}} \div\left[\left(Q_{i}+Q_{i}^{H}\right)-Q_{i}^{L}-\left(X_{i}+X_{i}^{I}\right)_{i}-C S_{i}+\left(M_{i}+M_{i}^{I}\right)\right]}{\sum_{i=1}^{n} Q_{i}^{D^{S E}} \div \sum_{i=1}^{n}\left[\left(Q_{i}+Q_{i}^{H}\right)-Q_{i}^{L}-\left(X_{i}+X_{i}^{I}\right)_{i}-C S_{i}+\left(M_{i}+M_{i}^{I}\right)\right]} \\
S I C A D_{i}^{S E}=\frac{I C A D_{i}^{S E}-1}{I C A D_{i}^{S E}+1} \times 100 \%
\end{gathered}
$$

where:

$Q_{i}^{D^{S E}}$ - volume of demand for goods $i$ on the domestic market, taking into account the shadow economy;

$I C A D_{i}^{S E}$ - index of comparative advantages of goods $i$ on the domestic market (in relation to imported one, taking into account the shadow economy);

$S I C A D_{i}^{S E}$ - symmetrical index of comparative advantages of goods $i$ on the domestic market;

$Q_{i}, Q_{i}^{H}, Q_{i}^{L}$ - production volume of goods $i$, hidden production (H), lohn production (L);

$X_{i}, X_{i}^{I}$ - export of goods $i$, illegal (I) export;

$C S_{i}$ - change in stocks of goods $i$;

$M_{i}, M_{i}^{I}$ - import of goods $i$, illegal (I) import.

The following sources of information were used to calculate $S I C A D_{i}^{S E}$ :

$\checkmark$ Production in natural expression by types of products;

$\checkmark$ Indicators regarding the circulation of industrial production in the Republic of Moldova competitiveness;

$\checkmark$ Retail trade by type of goods;

$\checkmark$ Harvest of main agricultural crops;

$\checkmark$ Harvest of fruits, berries and grapes;

$\checkmark$ Production of main animal products;

$\checkmark$ Volume of export and import by types of products; etc.

Volumes of hidden production, illegal import and illegal export in the goods division were 
calculated on the basis of the adapted inter-branch model (Gutium 2018: 41-42). The author used equation 3 to assess the competitiveness of more than 200 goods on the domestic market for 20142019. Table 1 shows the results of calculations for some goods.

The analysis of the dynamics of the comparative advantage index in the goods division showed that wheat, meslin, barley, oats, corn, sorghum grains, other grains are competitive on the domestic market. In recent years, the comparative advantages of both wheat and wheat flour have increased (table 1).

Table 1

Symmetrical index of comparative advantages of goods on the domestic market

\begin{tabular}{|c|c|c|c|c|c|c|}
\hline & 2014 & 2015 & 2016 & 2017 & 2018 & $2019 *$ \\
\hline $\begin{array}{l}\text { Wheat, meslin, barley, oats, corn, sorghum } \\
\text { grains, other grains }\end{array}$ & 38,06 & 36,74 & 36,58 & 35,15 & 37,33 & $38,01^{*}$ \\
\hline Wheat or meslin flour & 26,87 & 26,60 & 16,34 & 21,62 & 23,56 & $24,00^{*}$ \\
\hline Vegetables, fresh or chilled & 33,87 & 30,64 & 30,54 & 30,70 & 29,81 & $29,73^{*}$ \\
\hline $\begin{array}{l}\text { Milk and cream, without or with added } \\
\text { sugar or other sweetening matter }\end{array}$ & 30,71 & 30,81 & 25,08 & 20,71 & 25,62 & $26,31^{*}$ \\
\hline Cheese & 26,60 & 27,99 & 26,81 & $-46,82$ & $-36,45$ & - \\
\hline Sunflower-seed oil and its fractions & 32,01 & 30,68 & 30,80 & 23,97 & 26,81 & $27,00^{*}$ \\
\hline $\begin{array}{l}\text { Sausages and similar products, of meat, } \\
\text { meat offal or blood }\end{array}$ & 38,08 & 37,20 & 37,11 & 35,52 & 37,79 & $35,97^{*}$ \\
\hline $\begin{array}{l}\text { Beet sugar and chemically pure sucrose, in } \\
\text { solid state }\end{array}$ & 36,17 & 36,09 & 13,99 & 17,77 & 30,53 & $33,10^{*}$ \\
\hline Centrifugal pumps & $-97,22$ & $-96,39$ & $-99,81$ & $-93,87$ & $-95,86$ & $\stackrel{-}{96,43^{*}}$ \\
\hline Woodworking machine tools & $-100,0$ & $-93,57$ & $-86,25$ & $-100,0$ & $-99,74$ & $99,80^{-}$ \\
\hline Wool yarn & 37,61 & 36,35 & 34,02 & 32,72 & 32,54 & $32,59 *$ \\
\hline Carpets and other floor coverings & $-41,29$ & $-46,68$ & $-36,14$ & $-57,69$ & $-49,00$ & - \\
\hline Stockings, socks and the like & $-70,81$ & $-71,71$ & $-68,49$ & $-73,60$ & $-77,50$ & - \\
\hline Footwear & $-64,95$ & $-50,14$ & $-48,88$ & $-52,88$ & $-47,40$ & - \\
\hline Natural sands & 38,83 & 37,42 & 36,25 & 35,49 & 37,82 & $36,74^{*}$ \\
\hline Cement & 38,23 & 30,37 & 30,44 & 32,97 & 34,31 & $34,60 *$ \\
\hline Lime for construction & $-95,61$ & $-85,56$ & $-95,63$ & $-82,63$ & $-93,80$ & $\stackrel{-}{93,85^{*}}$ \\
\hline $\begin{array}{l}\text { Registers, account books, notebooks, order } \\
\text { books, receipt books, letter pads, diaries } \\
\text { and similar articles }\end{array}$ & 20,38 & 15,28 & 23,69 & 12,46 & 8,93 & $5,88^{*}$ \\
\hline $\begin{array}{l}\text { Organic surface-active agents (other than } \\
\text { soap); surface-active preparations, } \\
\text { washing preparations and cleaning } \\
\text { preparations }\end{array}$ & $-77,06$ & $-99,39$ & $-99,98$ & $-79,15$ & $-69,29$ & $69,90 *$ \\
\hline
\end{tabular}

Note: *) the calculations are performed based on provisional statistical data.

Source: Elaborated by the author.

Sausages made in Moldova are competitive on the internal market. In 2018, the Symmetrical Index of Comparative Advantages on the Domestic market (SICAD) of sausages and similar products increased by 2.27 percentage points. This growth was caused by a rise in consumer preferences for the purchase of sausages of domestic production and, accordingly, a reduction in demand for those 
imported. Imports of these goods diminished by $24.2 \%$ compared with 2017 . Namely, a growth of the import price by $16.1 \%$ affected the decrease in the demand for imported sausages. In the future, this product will not be able to expand its sales markets abroad, as the domestic livestock sector is in decline.

According to the author's calculations, in 2019 sunflower oil had comparative advantage of $27.00 \%$ on the domestic market. The competitiveness of this product is increasing on foreign markets. The increase in demand for vegetable oil made in Moldova by $23.61 \%$ on the market of European Union is due to the relatively low price of the delivered goods, which decreased by $8.35 \%$ compared to the previous year. The main European markets are Spain and Italy.

Vegetables are competitive on the domestic market, but not on the foreign market. During the years 2017-2019, the competitiveness of vegetables on the domestic market decreased due to acute competition. In 2018, the import of this category of goods registered a higher volume than that achieved in 2017 by $88.45 \%$, and in the following year (2019) it increased by $6.62 \%$ compared to 2018. In 2019, the main importer of cucumbers was Turkey (71.60\%), carrots, beets and other similar edible roots - Belarus (63.57\%), tomatoes - Turkey (58.12\%), onions and other allied vegetables Russian Federation (57.51\%), cabbage - Northern Macedonia (41.32\%).

Cheese, cottage cheese, feta cheese made in Moldova had comparative advantages on the domestic market compared to imported analogue goods up to 2016. But starting with 2017, this kind of goods got comparative disadvantage, because, in that year, the volume of its production suddenly decreased by $79.93 \%$ compared to the previous year. In addition, consumer preferences have changed in favor of quality ones, which are high in milk fat. According to the results of studies conducted in 2015-2016 by the Eastern European Foundation (FEE) and in 2017 by the Center for Applied and Certified Metrology (CMAC), "the milk fat content of a large number of dairy products manufactured in Moldova is very low and does not correspond technical regulations on dairy products" (Logos press 2018).

The author's calculations showed that some of the goods of the agro-industrial branch, which were not competitive, could become more competitive if the domestic producer would be supported by the state.

The analysis of comparative advantage of machine building industries' merchandises showed that the goods produced by the German company Dräxlmaier, which deliver electrical equipment, had the biggest advantages on the foreign market. However, this commodity has not comparative advantage on the domestic market, because it is lohn production, and it is not offered on the internal market.

Light industry goods have a comparative disadvantage, but the majority of building materials produced in the Republic of Moldova have comparative advantages on the internal market, since from the point of view of minimizing transportation costs it is more profitable to buy domestic goods than imported. One of the conditions for the development of this industry is a stable increase in disposable income and an increase in the well-being of the population.

During the years 2017-2019, the competitiveness of the manufacture of registers, account books, notebooks, order books, receipt books, letter pads, diaries decreased. Organic surface-active agents, surface-active preparations, washing preparations and cleaning preparations had a comparative disadvantage during the period under review (table 1). This branch has potential. Taking into account that the Covid-19 pandemic caused the increase of the demand for soap, disinfectant solutions, an effective management would ensure the increase of the competitiveness of these goods on the domestic market.

A NEW INTEGRAL INDEX FOR QUANTIFYING THE COMPETITIVENESS OF GOODS:

\section{ELABORATION AND APPLICATION}

The second task proposed by the author is to develop an integral index of the competitiveness of domestic goods on the internal market.

In the case of the integral index, a certain algorithm is used, which takes into account the factors of competitiveness. Some of the factors are estimated numerically, and others are qualitative. In the literature, the set of factors differs from one author to another, contains quantitative and qualitative factors (Sorokina et al. 2010:214), or only qualitative factors (Moseiko et al. 2017:4). The author 
proposes another algorithm for assessing the competitiveness of goods, which differs from those already known. The new algorithm takes into account the competitiveness factors of the goods listed in the previously published article (Gutium 2018:67).

The author's proposal consists in calculating, in the first stage, the following indicators:

where:

$$
C_{p}=\frac{p^{a}}{p^{m}} ; \quad C_{q}=\frac{q^{a}}{q^{m}} ; \quad C_{s}=\frac{s^{a}}{s^{m}} ; \quad C_{e}=\frac{e^{a}}{e^{m}} ; \quad C_{f}=\frac{f^{a}}{f^{m}},
$$

$C_{p}, C_{q}, C_{s}, C_{e}, C_{f}$ - competitiveness of the domestic goods, in relation to the imported goods, by price $(p)$, by the quality of the goods $(q)$, by after-sales service $(s)$, by marketing elements $(e)$, by psychological factors $(f)$;

$p^{a}, q^{a}, s^{a}, e^{a}, f^{a}$ - indicators of the analyzed domestic goods;

$p^{m}, q^{m}, s^{m}, e^{m}, f^{m}$ - indicators of the imported goods.

The integral index of competitiveness $\left(I_{c}\right)$ can be calculated according to the following formula:

$$
\begin{gathered}
I_{c}=\frac{b_{1}}{C_{p}}+b_{2} \times C_{q}+b_{3} \times C_{s}+b_{4} \times C_{e}+b_{5} \times C_{f}, \\
b_{1}+b_{2}+b_{3}+b_{4}+b_{5}=1,
\end{gathered}
$$

where:

$b_{1}, b_{2}, b_{3}, b_{4}, b_{5}$ - significance coefficients of competitiveness factors $(p, q, s, e, f)$.

If the significance of the factors to the consumer is identical, then:

$$
b_{1}=b_{2}=b_{3}=b_{4}=b_{5}=0,2 \text {. }
$$

The value of the impact of the price factor and the quality factor depends on the well-being of consumers. Price-quality ratio can be represented by a function dependent on the disposable income of consumers, in the case of a good manufactured by a particular producer (equation 8), and by a function dependent on the welfare of the population, in the case of a group of similar domestic goods (equation 9):

$$
\begin{aligned}
& \frac{b_{2}}{b_{1}}=f(Y-T), \\
& \frac{b_{2}}{b_{1}}=f\left(\frac{P I B}{N}\right),
\end{aligned}
$$

where:

$Y$ - consumer income;

$T$ - income tax;

$P I B$ - the gross domestic product;

$N$ - the number of habitually resident population.

The good is considered competitive when the integral index of competitiveness $\left(I_{c}\right)$ reaches values greater than or equal to 1 .

According to the author, among the factors of competitiveness, the first, which has to be evaluated, is price. Today, in the Republic of Moldova, a large part of the population prefers a cheap and relatively low-quality product, and not an expensive and high quality one. The causes of this trend are the low solvency, the devaluation of the national currency, inflation, wage retention, the wage gap, economic impact of the Covid-19 pandemic.

In 2018, the minimum subsistence, based on the stable population, was 1891 lei, the average monthly income available per person was 2060.2 lei, and in 2019 the indicators based on the habitually resident population were corresponding 2031.2 lei and 2880.6 lei. The comparative analysis of the minimum consumption basket with the disposable income of the population on quintiles showed, that in 2018, the disposable income of $40 \%$ of the stable population is lower than the subsistence minimum. Quintile II recorded the disposable income of 1824.1 lei, which is $96 \%$ of the minimum consumption basket (BNS 2020). Generalizing the above, we conclude, a considerable part of the population, places the price first in the list of parameters for assessing the competitiveness 
of domestic goods on the internal market. This tendency is cause by the relatively low level of income.

Domestic enterprises that promote manufactured goods on both domestic and foreign markets take into account national, regional and international standards, such as ISO, IEC, IEC and others. At the stage of assessing competitiveness in relation to quality, the parameters of goods are adjusted to the standards in force on the market. In the case of the internal market, comparative analysis is performed with the parameters of the imported analogue commodity. It is necessary to establish the compliance of the product parameters with the mandatory standards and regulations, which determine the level and limits of these parameters. If at least one of the parameters does not correspond to the mandatory level, which is prescribed by the current rules and standards, the goods cannot be considered competitive, regardless of the result of the comparison of other parameters.

Considering that four of the five groups of competitiveness factors need to be assessed by experts, the author offers a new approach to assessing the competitiveness of goods by quality on the domestic market, which allows making calculations based on available statistical data.

In developing a new approach, the author took into account that the higher the quality of the product, the higher the income elasticity of demand will be. Consequently, the competitiveness of domestic goods in relation to imported goods in quality can be calculated as the ratio between the income elasticity of demand for domestic goods $\left(E_{I}^{a}\right)$ and the income elasticity of demand for imported one $\left(E_{I}^{m}\right)$ :

$$
C_{q}=\frac{E_{I}^{a}}{E_{I}^{m}}=\frac{\Delta Q^{a} \%}{\Delta I \%} / \frac{\Delta Q^{m} \%}{\Delta I \%}=\frac{\Delta Q^{a} \%}{\Delta Q^{m} \%}=\frac{\delta Q^{a}}{Q^{a}} / \frac{\delta Q^{m}}{Q^{m}} .
$$

So:

$$
C_{q}=\frac{\delta Q^{a}}{\delta Q^{m}} \times \frac{Q^{m}}{Q^{a}}
$$

where:

$Q^{a}$ - the volume of the domestic goods realized on the domestic market;

$Q^{m}$ - the volume of the imported goods realized on the domestic market;

$I$ - disposable income.

Because elasticity can take both positive and negative values, we can encounter four situations.

Case I:

$$
\frac{\delta Q^{a}}{Q^{a}}>0 \quad \frac{\delta Q^{m}}{Q^{m}}>0
$$

Case II:

$$
\frac{\delta Q^{a}}{Q^{a}}>0 \quad \frac{\delta Q^{m}}{Q^{m}}<0
$$

Case III:

$$
\frac{\delta Q^{a}}{Q^{a}}<0 \quad \frac{\delta Q^{m}}{Q^{m}}>0 .
$$

Case IV:

$$
\frac{\delta Q^{a}}{Q^{a}}<0 \quad \frac{\delta Q^{m}}{Q^{m}}<0 .
$$

In case I we will apply equation 11 for the calculation $C_{q}$, and in case II we will consider that $C_{q}=1$, while in case III we will estimate $C_{q}=0$.

For case IV we will modify equation 11 , and we will use the following formula:

$$
C_{q}=\left(1+\frac{\delta Q^{a}}{Q^{a}}\right) /\left(1+\frac{\delta Q^{m}}{Q^{m}}\right) .
$$

The merchandise is competitive in quality if, as a result of the calculations, we get values greater than or equal to 1 .

In table 2 mono-factorial models of the competitiveness of goods are presented horizontally, and nonlinear bi-factorial models are above the diagonal. 
Table 2

Components of mono-factorial and nonlinear bi-factorial models of goods' competitiveness

\begin{tabular}{|l|c|c|c|c|c|}
\hline \multicolumn{1}{|c|}{ Factors } & $\begin{array}{c}\text { Price } \\
(\boldsymbol{p})\end{array}$ & $\begin{array}{c}\text { Quality of } \\
\text { goods } \\
(\boldsymbol{q})\end{array}$ & $\begin{array}{c}\text { After-sales } \\
\text { service } \\
(\boldsymbol{s})\end{array}$ & $\begin{array}{c}\text { Marketing } \\
\text { elements } \\
(\boldsymbol{e})\end{array}$ & $\begin{array}{c}\text { Psychological } \\
\text { factors } \\
(\boldsymbol{f})\end{array}$ \\
\hline Price $(\boldsymbol{p})$ & $b_{1} \frac{1}{p}$ & $b_{12} \frac{q}{p}$ & $b_{13} \frac{s}{p}$ & $b_{14} \frac{e}{p}$ & $b_{15} \frac{f}{p}$ \\
\hline Quality of goods (q) & & $b_{2} q$ & $b_{23} q s$ & $b_{24} q e$ & $b_{25} q f$ \\
\hline After-sales service $(\boldsymbol{s})$ & & & $b_{3} s$ & $b_{34} s e$ & $b_{35} s f$ \\
\hline Marketing elements $(\boldsymbol{e})$ & & & & $b_{4} e$ & $b_{45} e f$ \\
\hline Psychological factors $(\boldsymbol{f})$ & & & & & $b_{5} f$ \\
\hline
\end{tabular}

Source: Elaborated by the author.

Not all five groups of competitiveness factors are influencing factors for all kind of goods. For example, in the case of basic necessities, such as bread, dairy, the main influencing factors are price and quality, and the influence of the after-sales service factor is zero. Therefore, the competitiveness model of goods can contain only two exogenous variables, and the model can be linear or nonlinear.

In analyzing the results, we will focus on the agricultural sector, because Moldova is an agricultural state, and on manufacturing industries, because namely a developed industrial state, and not an agrarian state, can ensure a sustainable growth of the national economy.

The author applied the developed integral index to assess the competitiveness of some goods and presented the results of the calculations in table 3.

Table 3

Integral index of domestic goods on the internal market

\begin{tabular}{|l|c|c|c|c|c|c|}
\hline & $\mathbf{2 0 1 4}$ & $\mathbf{2 0 1 5}$ & $\mathbf{2 0 1 6}$ & $\mathbf{2 0 1 7}$ & $\mathbf{2 0 1 8}$ & $\mathbf{2 0 1 9}$ \\
\hline Wheat and meslin & 1,82 & 1,34 & 1,36 & 1,81 & 1,19 & 1,42 \\
\hline Barley & 1,25 & 1,26 & 1,01 & 1,00 & 1,40 & 1,48 \\
\hline Potatoes & 1,02 & 1,53 & 1,48 & 1,53 & 1,63 & 1,53 \\
\hline Tomatoes, fresh or chilled & 1,74 & 1,42 & 2,33 & 3,36 & 2,57 & 2,31 \\
\hline Onions and other allied vegetables & 1,49 & 1,14 & 1,69 & 2,60 & 1,60 & 1,99 \\
\hline Cucumbers and gherkins, fresh or chilled & 2,51 & 2,67 & 3,46 & 4,76 & 3,75 & 3,56 \\
\hline Grapes, fresh or dried table varieties & 4,15 & 3,80 & 3,31 & 5,62 & 6,85 & 6,01 \\
\hline Apples, pears and quinces, fresh & 6,27 & 2,47 & 3,43 & 3,47 & 3,14 & 3,16 \\
\hline $\begin{array}{l}\text { Apricots, cherries, sour cherries, peaches } \\
\text { (including nectarines), fresh plums }\end{array}$ & 7,76 & 6,94 & 5,59 & 3,53 & 3,53 & 5,30 \\
\hline $\begin{array}{l}\text { Milk and cream, without or with added } \\
\text { sugar or other sweetening matter }\end{array}$ & 2,08 & 2,22 & 1,79 & 1,25 & 1,16 & $1,67^{*}$ \\
\hline $\begin{array}{l}\text { Crude sunflower-seed oil and safflower oil } \\
\text { and their fractions, not chemically modified }\end{array}$ & 1,24 & 1,35 & 1,16 & 1,14 & 1,31 & $1,39^{*}$ \\
\hline Margarine & 0,64 & 0,75 & 0,53 & 0,81 & 0,67 & $0,68^{*}$ \\
\hline $\begin{array}{l}\text { Other prepared or preserved meat, meat } \\
\text { offal or blood }\end{array}$ & 0,50 & 0,83 & 0,62 & 0,60 & 0,99 & $0,97^{*}$ \\
\hline Wool & 1,55 & 1,27 & 0,97 & 1,66 & 2,49 & 3,36 \\
\hline Carpets and other floor coverings & 0,72 & 0,58 & 0,38 & 0,47 & 0,71 & $0,48^{*}$ \\
\hline Stockings, socks and the like & 0,91 & 0,57 & 0,46 & 0,60 & 0,72 & $0,68^{*}$ \\
\hline Footwear & 0,28 & 0,48 & 0,37 & 0,29 & 0,55 & $0,24^{*}$ \\
\hline
\end{tabular}

Note: *) the calculations are performed based on provisional statistical data.

Source: Elaborated by the author. 
Of the set of goods analyzed, only some of the domestic goods are competitive by price, such as cereals, barley, onions, grapes, natural honey, apricots, cherries, peaches (including nectarines), plums, apples, pears and quinces, etc. Consequently, mainly unprocessed primary products are competitive on the domestic market, but a lot of highly processed products, high-tech products are not competitive.

In the Republic of Moldova, the technological gap with the main trading partners is growing and, consequently, the competitive potential of many processed goods is declining. Some of products offered by the manufacturing industry are lohn production. The analysis of the competitiveness of domestic goods on the internal and foreign market showed that in the case of many products, the higher the degree of processing, the lower the competitiveness of these goods in comparison with imported similar goods (Gutium 2018:73).

The analysis of the correlation between competitiveness and the level of economic, scientific and technological development of the country showed that the correlation is negative in case of unprocessed primary products, and the correlation is positive in case of high value-added processed goods and high-tech goods (Pojsik 2018:13).

For determining the directions of specialization and the set of goods that need to be promoted on the foreign market, the author proposes the following integral index of the competitiveness of domestic goods on the foreign market, which has included a new component:

$$
\begin{gathered}
I_{c}^{e x}=\frac{b_{1}}{C_{p}^{x}}+b_{2} \times C_{q}^{x}+b_{3} \times C_{s}^{x}+b_{4} \times C_{e}^{x}+b_{5} \times C_{f}^{x}+G_{t}, \\
C_{p}^{x}=\frac{p^{x}}{p^{m}} ; \quad C_{q}^{x}=\frac{q^{x}}{q^{m}} ; \quad C_{s}^{x}=\frac{s^{x}}{s^{m}} ; \quad C_{e}^{x}=\frac{e^{x}}{e^{m}} ; \quad C_{f}^{x}=\frac{f^{x}}{f^{m}},
\end{gathered}
$$

where:

$C_{p}^{x}, C_{q}^{x}, C_{s}^{x}, C_{e}^{x}, C_{f}^{x}$-competitiveness of the exported goods, in relation to the imported goods, by price $(p)$, by the quality of the goods $(q)$, by after-sales service $(s)$, by marketing elements $(e)$, by psychological factors $(f)$;

$G_{t}$ - the degree of technological intensity of the manufacture of the analyzed domestic goods;

$p^{x}, q^{x}, s^{x}, e^{x}, f^{x}-$ indicators of the exported goods.

The degree of technological intensity of the manufacture of the goods can be determined using the Expert Judgment method. In the case of the limited time and human resources required to evaluate this indicator, the author proposes to use the following method.

The products can be divided according to the processing level into: unprocessed primary products; semi-processed products; processed products; high-tech products. Each product group can be given the following score (table 4):

Table 4

Estimation of the degree of technological intensity of the manufacture of the goods

\begin{tabular}{|l|c|}
\hline $\begin{array}{l}\text { Unprocessed primary products (cereals, fruits, fresh vegetables, raw hides, agricultural } \\
\text { wool, etc.) }\end{array}$ & $G_{t}$ \\
\hline $\begin{array}{l}\text { Semi-processed products (flour, vegetable oils, refined sugar, tanned hides and skins, } \\
\text { woolen yarn, etc.) }\end{array}$ & 1.0 \\
\hline Processed products (cheese, cheese, wine, canned meat, juices, stockings, clothing, etc.) & 1.5 \\
\hline High-tech products (means of transport, equipment, electronic products, etc.) & 2.0 \\
\hline
\end{tabular}

Source: Elaborated by the author.

The author used the developed integral index, took into account the available resources, human potential, and based on the calculations made conclusion that the priority sectors that need to be developed are the manufacture of: bicycles, scooters; submersible pumps; sports equipment for fitness centers; children's sports suits for outdoor play; lighting installations, led installations; drugs; antifreeze liquid; organic surface-active agents, surface-active preparations, washing preparations 
and cleaning preparations; cosmetics; food concentrates and sublimated products; essential oils; sleeping bags, tents; overalls; and so on.

All branches of the national economy, including the agro-industrial, have potential. The main directions for improving the competitiveness of goods, in the current conditions, are: modernization of the processing industry; introduction of innovations; liberalization of trade relations; diversification of goods; supporting agricultural producers, enterprises that procure hi-tech equipment and create new jobs; promoting antitrust policy and improving product quality that should meet the standards of both the European Union and the Eurasian Union. The Republic of Moldova must not give up either the European or the Eurasian market.

CONCLUSIONS

The researcher has achieved the basic goals. The novelty of the research consists in the elaboration of the integral index of the competitiveness of the domestic goods on the internal and external market, and in the improvement of the symmetrical index of the comparative advantage by including a new factor of influence. The estimation of the competitiveness of the goods using the developed indicators showed that on the internal market the unprocessed primary products and the processed products with a low degree of technological intensity of the manufacture of goods are mainly competitive.

The calculations performed with the help of the integral index of the competitiveness of domestic goods on the foreign market showed that mainly the most competitive in the analyzed period were the unprocessed primary products and semi-processed products. In addition, based on the results obtained, the priority sectors were determined: sub-branches of the machine building industry, light industry, chemical industry, food industry, etc.

\section{REFERENCES}

1. AL-SHUAIBI, K., ZAIN, M., KASSIM, N. Performance indicators for quality, innovation, and competitiveness: a survey on the Saudi manufacturing sector. In: International Business Research. 2016, vol. 9, issue 2, pp. 99-113. ISSN 1913-9004.

2. BALASSA, B., NOLAND, M. „Revealed” Comparative Advantage in Japan and the United States. In: Journal of Economic Integration. Autumn 1989, vol. 4 (2), pp. 8-22. ISSN 1225-651X.

3. BARATTIERI, A. Comparative advantage, service trade, and global imbalances. In: Journal of International Economics. 2014, vol. 92, issue 1, pp. 1-13. ISSN 0022-1996.

4. BERKOWITZ, D., MOENIUS, J., PISTOR, K. Trade, law, and product complexity. In: Review of Economics and Statistics. 2006, vol. 88, issue 2, pp. 363-373. ISSN 0034-6535.

5. COSTINOT, A., DONALDSON, D., KOMUNJER, I. What goods do countries trade? A quantitative exploration of Ricardo's ideas. In: Review of Economic Studies. 2012, vol. 79, issue 2, pp. 581608. ISSN 0034-6527.

6. DALUM, B., LAURSEN, K., VILLUMSEN, G. Structural change in OECD export specialisation patterns: de-specialisation and 'Stickiness'. In: International Review of Applied Economics. 1998, vol. 12, issue 3, pp. 447-467. ISSN 0269-2171.

7. GRUPP, $\mathrm{H}$. The measurement of technical performance of innovations by technometrics and its impact on established technology indicators. In: Research Policy. 1994, vol. 23, issue 2, pp. 175193. ISSN 0048-7333.

8. GUTIUM, T. Classification of the competitiveness' factors and new approaches to assessing the competitiveness. In: Economy and sociology. 2018, no. 2, pp. 65-74. ISSN 1857-4130.

9. GUTIUM, T. Quantifying the comparative advantage of domestic goods on the internal market. In: The Journal Contemporary Economy. 2018, vol. 3, issue 1, pp. 38-45. ISSN 2537-4222.

10. HAUSMANN, R., HIDALGO, C. The network structure of economic output. In: Journal of Economic Growth. 2011, vol. 16, issue 4, pp. 309-342. ISSN 1381-4338.

11. HIDALGO, C., KLINGER, B., BARABASI, A., HAUSMANN, R. The product space conditions the development of nations. In: Science. 2007, vol. 317, issue 5837, pp. 482-487. ISSN 1095-9203.

12. "Moločka" bez moloka: čto obnaružili èksperty? In: Èkonomičeskoe obozrenie. Logos press. 2018, № 3 (1217) [citat 5 februarie 2019]. Disponibil: http://p.logos.press.md/node/64665 
13. MOSEIKO, V., KOROBOV, S., FROLOV, D. Socio-Economic Systems' Competitiveness Assessment Method. In: Asian Social Science. 2015, volume 11, issue 20, pp. 1-9. ISSN 1911-2017.

14. Nivelul de trai al populației. Biroul Național de Statistică al Republicii Moldova [citat 11 aprilie 2020]. Disponibil:

https://statbank.statistica.md/pxweb/pxweb/ro/30\%20Statistica\%20sociala/30\%20Statistic a\%20sociala_04\%20NIV__04\%20NIV\%202019/?rxid=b2ff27d7-0b96-43c9-934b42e1a2a9a774

15. PENEDER, Michael. Competitiveness and industrial policy: from rationalities of failure towards the ability to evolve. In: Cambridge Journal of Economics. 2017, vol. 41, issue 3, pp. 829-858. ISSN 0309-166X.

16. POJSIK, M. Dostiženiâ so znakom minus. V: Argumenty i facty. 2018, № 45, c. 13 [citat 11 aprilie 2020]. Disponibil: https://aif.md/dostizhenija-so-znakom-minus/

17. POPA, A., PARMACLI, D., BABII, L. Economia antreprenoriatului. Cahul: Tipografia „Centrografic”, 2017. 277 p. ISBN 978-9975-88-015-2.

18. SAFIULLIN, N., SAFIULLIN, L. Konkurentosposobnost': teoriâ i metodologiâ. Kazan': Centr innovacionnyh tehnologij, 2008. 162 p. ISBN 978-5-93962-314-8 [citat 11 aprilie 2020]. Disponibil: https://www.elibrary.ru/item.asp?id=19885673

19. SIGGEL, E. International competitiveness and comparative advantage: a survey and a proposal for measurement. In: Journal of Industry, Competition and Trade. 2006, vol. 6, issue 2, pp. 137159. ISSN 1573-7012.

20. SOROKINA, G., SOTNICOV, A., ZAHAROV, A. Problemy ocenki konkurentosposobnosti produkcii avtomobilestroeniâ. V: Izvestiâ MGTU «MAMI». 2010, № 2 (10), ss. 214-219. ISSN 2074-0530. [citat 15 aprilie 2020]. Disponibil: https://cyberleninka.ru/article/n/problemy-otsenkikonkurentosposobnosti-produktsii-avtomobilestroeniya/viewer

21. YU, R., CAI, J., LEUNG, P. The Normalized Revealed Comparative Advantage Index. In: The Annals of Regional Science. 2009, vol. 43, issue 1, pp. 267-282. ISSN 0570-1864.

22. UN Comtrade Database [citat 21 aprilie2020]. Disponibil: https://comtrade.un.org

ARTICLE HISTORY

Received 01 June 2020

Accepted 12 June 2020 